\title{
Access to and use of public library services in Nigeria
}

\author{
Abdulsalam Abiodun Salman', Tinashe Mugwisi ${ }^{2}$ and Bertha Jantine Mostert ${ }^{3}$ \\ salbiodun@gmail.com ORCiD: orcid.org/0000-0002-6365-7371 \\ tmugwisi@gmail.com ORCID: orcid.org/0000-0001-9307-3927 \\ mostertb@unizulu.ac.za ORCID: orcid.org/0000-0001-8239-1225
}

\begin{abstract}
Received: 22 February 2017
Accepted: 7 July 2017

The study investigated the factors hampering access to and use of public library (urban and rural) services in Nigeria. Both quantitative and qualitative research methods were employed through the administration of a questionnaire to users in both urban and rural public libraries in Nigeria and conducting interviews with the public librarians. The objectives of the study centred on identifying awareness and utilisation of library services, including utilisation patterns. The study also sought to investigate levels of satisfaction among users as well as make recommendations for improved service delivery. The population was the registered public library user group from which 394 users were randomly sampled from twelve purposively selected libraries - two from each of the six regions. The respondents were mainly an educated male user group representing a wide variety of occupations. Awareness of services was restricted to a few services, and accessibility to the major library services was found to be a challenge to many. Utilisation patterns indicated infrequent use of only a few services, and very low satisfaction with what is being offered. Challenges identified included unawareness of services, too few copies of materials and lack of information literacy skills. Recommendations included the enhancement of community participation in decision-making concerning services, that relevant and enough materials be supplied, and that effective marketing be employed to improve access and to promote services among users and potential users.
\end{abstract}

Keywords: Public library access, Public library use, Public library services, Public library users, Nigeria.

\section{Introduction}

Access to and use of public library services are fundamental human rights which cannot be ignored. The Universal Declaration of Human Rights (UDHR), established in 1948, emphasises the right of individuals to provide, access, and use information (United Nations 2008). Article 19 of the Universal Declaration of Human stipulates that,

Everyone has the right to freedom of opinion and expression; this right includes freedom to hold opinions without interference and to seek, receive and impart information and ideas through any media and regardless of frontiers" (UDHR, 1948).

Furthermore, Article 27 stipulates that "Everyone has the right freely to participate in the cultural life of the community, to enjoy the arts and share in scientific advancement and its benefits.

The IFLA Public Library Service Guidelines (Koontz \& Gubbin 2010) describes the public library as an institution that provides access to knowledge, information and works of the imagination through a range of resources and services, while the IFLA/UNESCO Public Library Manifesto (1994) states that a public library is a local gateway to knowledge by providing the basic conditions for lifelong learning, independent decision-making and cultural development of an individual and social groups. Appraising the indices of access to and use of public library services in Nigeria, Obasi (2015) posited that a public library should be seen as the embodiment of the principle of the right to access and use information and to acquire knowledge. His study established that the development of public libraries in Nigeria has been low owing to the limited number of branch libraries, unavailability of information and communication technologies, an inadequate rural information network, inadequate literacy and the lack of mobile library services, community information, human resources and information resources. These findings imply that awareness of, access to and use of public libraries is affected by the availability of the quantity and quality of resources and services. As the Nigerian government is spending valuable financial and human resources providing library services to the general public, it is therefore important to establish the reasons for the lack of support for these services and how it can be addressed so that public libraries can fulfil the roles designated to them in the IFLA guidelines (2010).

1. Abdulsalam Abiodun Salman is a PhD graduate of the Department of Information Studies, University Of Zululand

2. Tinashe Mugwisi is Associate Research Fellow in the Department of Information Studies, University of Zululand

3. Bertha Jantine Mostert is Research Fellow in the Department of Information Studies, University of Zululand 


\section{Purpose of the study}

A number of recent studies on Nigerian public library utilisation support the findings of Obasi (Omekwu and Echezona 2009; Ikenwa and Adegbilero-Iwari 2014; Oluwaseunfunmi 2015). These studies looked at the issues mainly from the perspective of selected or small user groups, and very seldom included the view of the librarians on these issues. This study set out to establish the current levels of access to the services and facilities offered by the public library system in the whole of the country, and to gauge the use thereof, and satisfaction with service delivery among the public library users. In addition, the view of the librarians are included, providing a broader perspective on the issues at hand. The objectives of the study were to:

- identify the awareness and accessibility of services currently offered by the public libraries;

- $\quad$ establish the utilisation patterns among library users;

- examine the factors impacting on access and use of the available public library services;

- investigate the level of satisfaction among the users concerning the public library services rendered to them; and

- make recommendations on the improvement of public library service delivery in Nigeria.

\section{Literature review}

Amodeo and Carter (1999) posited that the services provided by public libraries are essential for both individual and collective development, as public libraries are the only libraries that make their services available to all members of the community, without any form of discrimination. Services provided by public libraries can vary in terms of responsibilities, which include individual support and development, commerce, and social and cultural advancement (Uzuebgu and Onyekweodiri 2011). Oyeronke (2012) advocated that the main concern of public library services is to provide timely, accurate, current and reliable information to a community served. Public libraries could also render services such as lifelong learning by providing a range of material on a variety of topics which will allow people to follow their interests and support them in the development of their formal and informal education (Amodeo and Carter 1999).

Accessibility in a library environment refers to unrestricted access to public library services. To Clarke et al. (2011), access to public library services to all members of the community addresses the issue of equality in a community, with no form of discrimination against any potential user. Adeniyi and Subair (2013) advocated that the services of a library can only be easily accessed if the library is centrally located in a community and the documents therein are described in accordance with standardised cataloguing and classification procedures. Additionally, they point out that public library services should be repackaged and disseminated through rural information dissemination activities in public libraries and community centres in order to be accessible to the rural illiterate. Ocholla's (2006) study looked at information accessibility via public libraries to South African marginalised communities, and found it to be poor because of the libraries' inconvenient locations, and the formats in which information was made available to those who wanted it. The formats available in the public libraries studied were found to be mainly aimed at users from information-rich environments. Bamise and Oyedapo (2012) pointed out that the accessibility of public library services in Nigeria has always been challenged as services are not made readily available to users, and information resources are in most cases outdated or irrelevant. They observed that the services that were the most accessible and used in most Nigerian public libraries were the photocopying service and the Nigerian newspapers provided, which by government policy are delivered on a regular basis to all the parastatals.

Utilisation in a public library refers to the ability of library users to use the services in the library for gaining information, or for entertainment purposes. The achievement of the set objectives of a public library is closely related to the level of use of the services offered by the intended community. Obinyan, Obinyan and Aidenojie (2011), in their study on usage patterns in four branches of a state public library in Nigeria, found that students and youths mostly frequented the public libraries in a quest for information that can be used for examination purposes, or just for personal enlightenment. A study conducted at the Delhi public library (Tyagi 2011) established that the library was mostly used on a daily basis by people who were retired and unemployed, while Adeniyi and Subair (2013), in their study of illiterate rural communities, found that additional library services - such as repackaging of information - were required to improve use of library services among community members. These findings seem to indicate that, in most libraries, user patterns are linked to distinct groups making use of the library facilities.

Within the African context, underutilisation remains a huge problem which the Zambia Library Association (1987) and Abolaji (2009) ascribe to dispersed populations, poor transportation, lack of communication systems, illiteracy, lack of financial resources, inappropriateness in the provision of library collections and services, a poor economy, and the unavailability of community information. According to Iwhiwhu and Okorodudu (2012) and Kim-Soon, Hasbi and Ahmad (2013), ensuring customer satisfaction within the public library services depends on the provision of good quality and quantity of the services for learning, information and research. The study done by Ikenwe and Adegbilero-Iwari (2014) among public libraries in the south-west region of Nigeria established that the level of customer satisfaction affects the use or non-use of library services. They found that the large majority of library users were not satisfied with the library service rendered, citing issues such as the lack of adequate facilities, inadequate/outdated information resources, and inadequate internet/ICT services as major reasons for their lack of satisfaction. These complaints clearly indicate that services that meet patrons' expectations and satisfy their needs should be provided by public libraries. 


\section{Contextualisation: an overview of public library development in Nigeria}

Within the Nigerian context, public library development is linked to the history of education and colonial settlement, with the first public library system established in northern Nigeria in 1952. From the onset, several challenges were experienced, such as inappropriate reading materials, inadequately trained staff and their fear of being held responsible for lost materials, high illiteracy rates, and the lack of a reading culture - all of which hampered proper use of the available services (Harris 1970: 49; Salman 2006:13). At the UNESCO seminar on the development of public libraries in Africa held in Ibadan, Nigeria, in 1953, a decision was taken that appropriate legislation be put in place to ensure the development of public libraries in Nigeria, and that the control of the libraries be put in the hands of a state agency that would be established by the federal government (UNESCO 1953). Coinciding with the advent of free primary education, public libraries, as institutions that could, on the one hand, provide continuing education for children who had to exit the school system at an early age, and on the other hand, act as a remedy for existing educational deficiencies, were welcomed by both the government and the general public (Obasi 2015).

Public library services in Nigeria, however, experienced a decline in the quality of service delivery after the advent of national independence in 1960, as a result of the unstable economic and political structure in the country (Omotosho 2014). Access to and use of public libraries is, then, affected by availability of the quantity and quality of resources and services. According to Ojo-Igbinoba (1993), despite these setbacks, steady development of public or state regional libraries has taken place since 1967. Currently, there are 316 public libraries in Nigeria (Librarians' Registration Council of Nigeria 2015), including thirty-six Public Library Boards and the National Library of Nigeria. Governance of public libraries in Nigeria is essentially the responsibility of the government because the public library is regarded as a service institution, established and managed with public funds. Despite the fact that public libraries were recognised as instruments of general education and social welfare for the general population long before the modern states' legal frameworks existed, many countries, both developed and developing, have not yet promulgated effective public library legislation (Gardner 1971:17). Within Nigeria, the lack of effective public library legislation has hindered the growth and development of library services in the country (Yusufu 2010). Although legislation such as the National Library Act of 1970, and the National Library of Nigeria Legal Deposit Law exist, they are not sufficiently regulating the services required by communities in the country. The management and administration of libraries are overseen by the National Library of Nigeria, in conjunction with the State Library Board of each state. Libraries are normally situated in urban areas and have a Library Board that is responsible for its affairs and that of its affiliated rural libraries (Ogbonna 2014). These Library Boards are accountable to the ministry for the administrative responsibilities of managing the libraries, the provision of services such as acquisition and organisation of materials, and the funding of information services such as photocopying and scanning services.

According to Iwhiwhu and Okorodudu (2012), the physical infrastructure mostly found in Nigerian public libraries includes tables, chairs, lighting, ventilation, flooring, bookshelves, library space, fans, a circulation desk, photocopiers, study carrels, computers, periodical racks, binding machines, meeting halls, vehicle parking spaces and restaurants. In terms of available services, Iwhiwhu and Okorodudu (2012) established that resources such as fiction books, non-fiction books, textbooks and newspapers/magazines are commonly found in the public libraries, whereas posters, records and tapes, pictures, fax machines, audio-visual material, Braille material, CD-ROMs and toys are less commonly found. According to the Librarians' Registration Council of Nigeria (2015), print material still dominates the available book material with $21,382,356$ books being available, though recently 26,147 items of e-material have been made available in twelve of the State Board libraries. In terms of ICT facilities, 1,593 desktop computers, seventy-nine laptops, 169 printers and eightyseven photocopiers are available within the public library system, though not always for the sole use of the public. Internet connectivity was only reported in fifteen State Board libraries (Librarians' Registration Council of Nigeria 2015). Ebiwolate (2010) found that services such as bookmobile services, information and referral services, outreach programmes, current awareness programmes, children's library services, selective dissemination of information, and entertainment services are also less commonly found in the majority of the Nigerian public libraries.

\section{Methodology}

According to Creswell and Plano Clark (2007), a research design helps guide and direct the collection and analysis of data. For this study, a case study design was adopted. A case study allows for both qualitative and quantitative methods to be used and was preferred to a purely statistical survey so that a more realistic picture of the views of both the user population and the librarians under study could be painted. The population were the 29,277 registered public library users in Nigeria as well as the librarians in the libraries targeted. Using Israel's (1992) sampling model, 394 users were sampled, and one librarian in each library. Within each of the six regions of Nigeria, one State Board library, and one rural library were purposively selected. Purposive sampling was used because of the extremely large distances between geographical areas within each region, and for both political and security considerations, which did not always make it possible to select a sample using a more structured method. The users were selected using convenience sampling, targeting those that were available in the library. The librarians were selected purposively, as the views of the most qualified and informed library staff were required.

After permission was obtained from the Ministry of Education, Science and Technology, the data were collected by way of a questionnaire to users in both urban and rural public libraries. Structured interviews were used to elicit the views of the librarians. The questionnaires were distributed to users conveniently available in each library. Of the 394 users sampled, $363(92.1 \%)$ returned usable questionnaires. A reason for the high return rate was the fact that the researchers waited for the users to complete and return the questionnaires. However, in the case of two of the rural libraries, no responses were received as no users visited the library during the period of the study. Even when questionnaires were left 
with the librarians for later retrieval, no respondents were found. Appointments to interview each librarian were made. The Statistical Package for the Social Sciences (SPSS) was used to sort, code and analyse the quantitative data. This software was used as it had the ability to process, organise and interpret large quantities of data (Polit \& Beck 2004). The interview answers were analysed and grouped together according to theme.

\section{Results and discussions}

The findings are discussed in the sections that follow.

\subsection{Demographic characteristics of respondents}

To establish the profile of the library user respondents, a number of demographic questions such as gender, age, occupation and qualification were asked. As the questionnaires were given only to registered library users, it can be assumed that this profile will provide a glimpse of what the user profile of public libraries in Nigeria looks like in general.

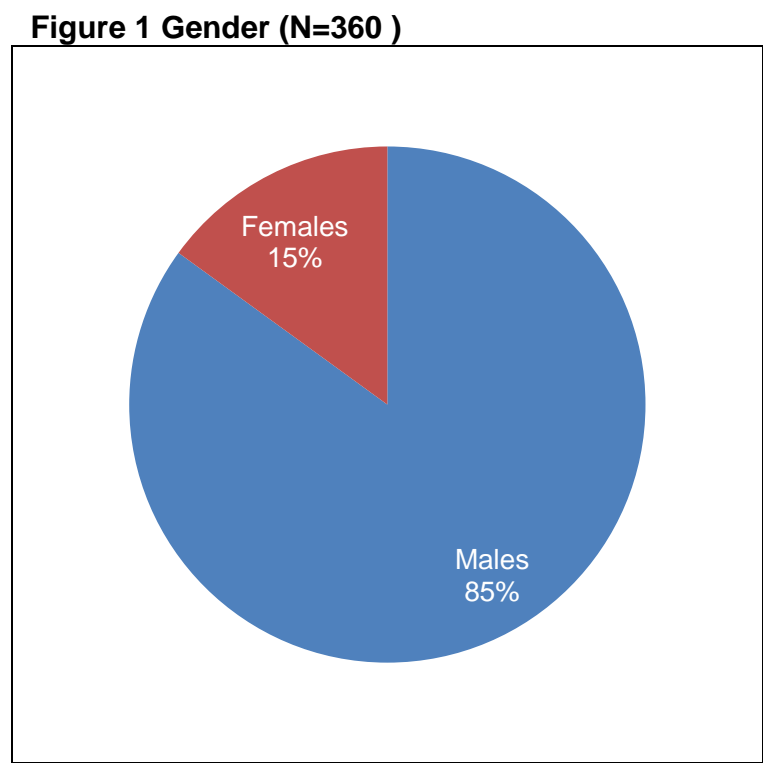

Figure 2 Age groups $(\mathrm{N}=360)$

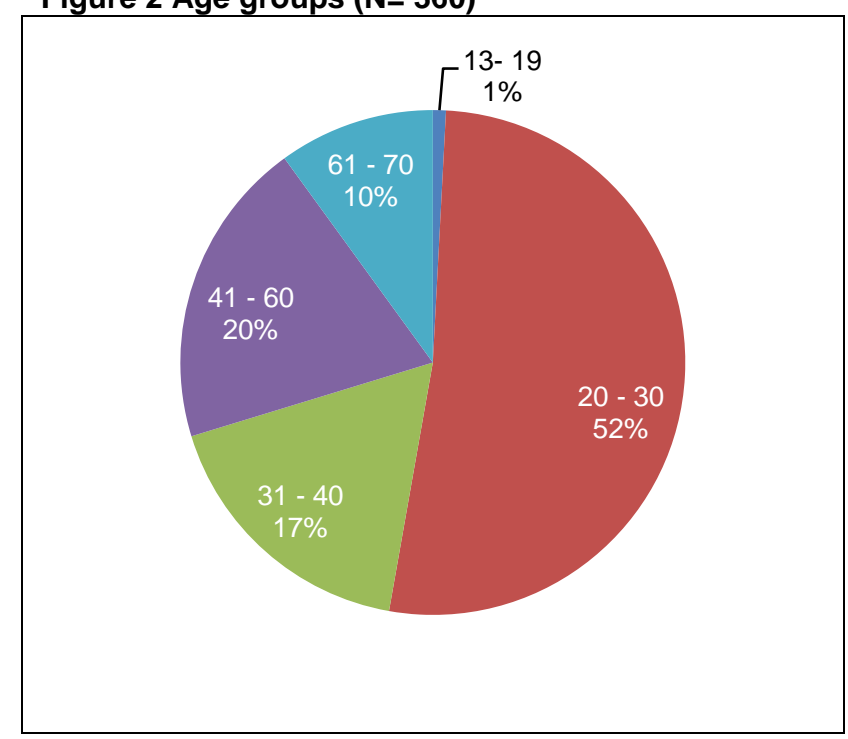

The responses (Figure 1) indicated a predominance of male users (85\%) over that of female users (15\%). Interesting to note was that this male predominance was even more pronounced in the northern regions of the country, which could possibly be attributed to stricter religious and social structures than in the southern regions (Badawi 2009).

Figure 2 indicates that more than half $(190 ; 53 \%)$ of the respondents were younger than 30 years old, while the older generation of 40 years and above only made up $107(30 \%)$ of the total response. The reason for the interest in using the library among the younger generation might be employment-related, as Salman (2016) found that most of the young people using the libraries were doing so with the aim of scanning or printing documents required for employment or university applications, or finding information related to schoolwork or their tertiary education.

The qualifications of the respondents, as reflected in Table 1, show a well-educated user group. As the study did not target non-users, this does not necessarily mean that the information reflected in the study is an accurate reflection of the community at large. Nor does it mean that the libraries are mainly providing services to a largely literate community, while those who are in desperate need of information, such as illiterates and semi-literates, are not efficiently catered for by way of the available services in the libraries. Saleh and Lasisi (2011) found that up to $90 \%$ of all information material provided in Nigerian public libraries comprised print-based monographs - sources which are inaccessible to the illiterate.

Table 1 Qualifications $(\mathrm{N}=360)$

\begin{tabular}{lcc}
\hline Qualification & Number & $\%$ \\
\hline Bachelor's degree & 109 & 30.3 \\
Diploma & 56 & 15.6 \\
National Certificate & 53 & 14.7 \\
Primary schooling & 8 & 2.2 \\
Secondary Senior Certificate & 118 & 32.8 \\
Informal education & 16 & 4.4 \\
Total & 360 & 100 \\
\hline
\end{tabular}

Figure 3 illustrates that the most active user group is students with $155(43.1 \%)$ respondents, followed by the unemployed $(53 ; 14.7 \%)$, and civil servants with forty-nine (13.6\%). The high number of students using the public libraries 
seems to be consistent with reports from several studies over the last decade or two, for example, those of Opaleke (1997) and Obinyan, Obinyan and Aidenojie (2011). The high number of students might be attributed to the fact that the library is seen as a safe and quiet haven for young people and children to visit, either to wait for their parents to fetch them after work, or to do their schoolwork or study (Obinyan, Obinyan and Aidenojie, 2011; Salman 2016). Those unemployed and some of the students indicated that they used the library to look for job vacancies.

Figure 3 Occupations $(\mathrm{N}=360)$

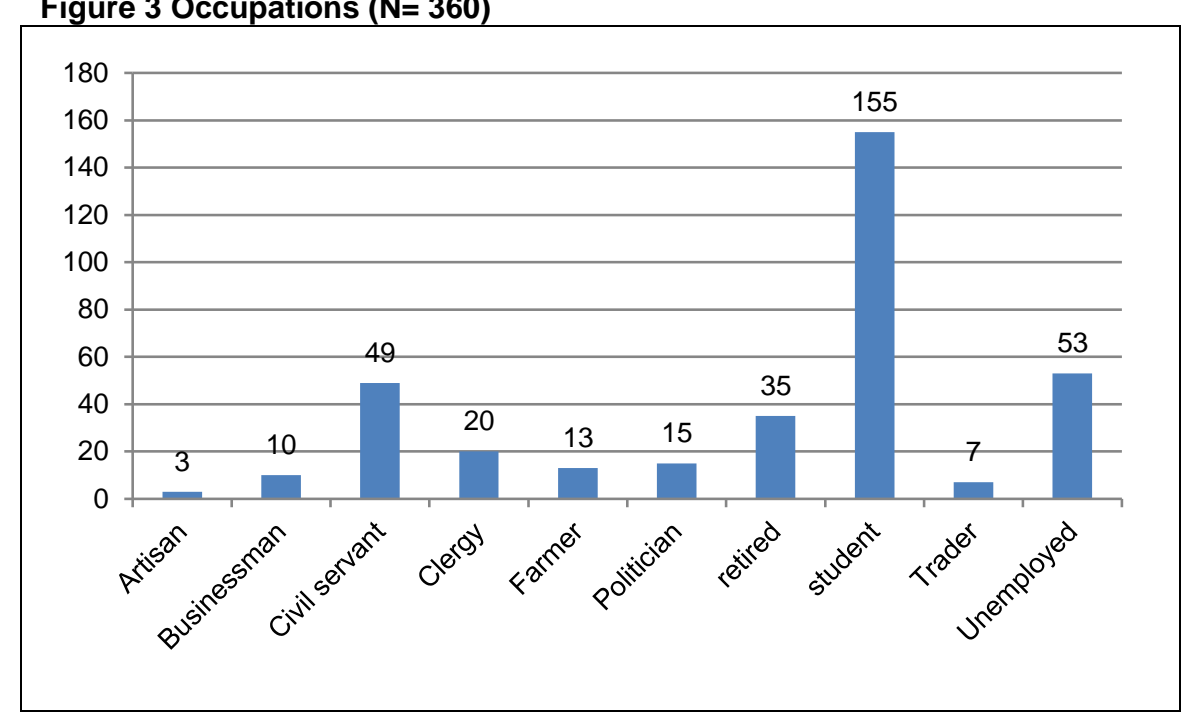

The librarians were required to provide their designation, highest qualification and their years of experience. These are reflected in Table 2. From the table, it is clear that the urban librarians have many more years of experience and hold higher qualifications as compared to their rural counterparts.

Table 2 Demographic information of librarians $(\mathrm{N}=12)$

\begin{tabular}{|c|c|c|c|}
\hline Respondent & Designation & $\begin{array}{l}\text { Years of } \\
\text { Experience }\end{array}$ & Highest Qualification \\
\hline \multicolumn{4}{|c|}{ Urban libraries } \\
\hline 1 & Director & 28 & Master's in Library and Information Science \\
\hline 2 & Director & 32 & Master's in Library and Information Science \\
\hline 3 & Executive Director & 23 & Bachelor of Library and Information Science \\
\hline 4 & Deputy Director & 34 & Bachelor of Library and Information Science \\
\hline 5 & $\begin{array}{c}\text { State } \\
\text { Librarian/Director }\end{array}$ & 24 & Master's' in Library and Information Science \\
\hline 6 & Executive Director & 31 & Bachelor of Library and Information Science \\
\hline \multicolumn{4}{|c|}{ Rural libraries } \\
\hline 7 & Library Officer & 6 & National Certificate of Education \\
\hline 8 & Library Officer & 16 & Diploma in Library Science \\
\hline 9 & $\begin{array}{c}\text { Assistant Chief Library } \\
\text { Officer }\end{array}$ & 12 & Diploma in Library Science \\
\hline 10 & Librarian II & 7 & Bachelor of Library and Information Science \\
\hline 11 & $\begin{array}{l}\text { Assistant Library } \\
\text { Officer }\end{array}$ & 4 & Higher National Diploma in Library and Information Science \\
\hline 12 & $\begin{array}{c}\text { Assistant Chief Library } \\
\text { Officer }\end{array}$ & 18 & Diploma in Library Science \\
\hline
\end{tabular}

\subsection{Awareness of services offered by the public libraries in Nigeria}

The use of sources and services offered by public libraries is only possible if a user is aware of what is available or on offer; and therefore this question aimed to establish the level of awareness of the services and resources that are commonly offered by public libraries. The result is shown in Table 3.

An awareness of available resources and services seems to be limited to a very few of those on offer, with awareness of the availability of newspapers $(292 ; 81.1 \%)$, bag cabinets to lock away belongings while using the library (289; $80.3 \%)$, and children's library services $(276 ; 76.7 \%)$ ranking among the highest, while a relatively large number of services and resources received a very low awareness response rate, or no responses at all. Abdel-Motey and Al-Ansari (2012) found 
the same trend in their study, and while attributing it to factors such as low funding, staff issues and outdated materials, they also warned that the obvious lack of information services in most of the public libraries should be a cause for grave concern among library professionals. The lack of awareness of the existence of certain library services and resources was found to be more prominent among the rural libraries. One of the most common services offered by libraries - the borrowing of information materials - received an awareness response of zero. This response could possibly be attributed to a general lack of materials available for borrowing, or the services not being offered because of previous library experiences of high non-return rates of borrowed material.

Though there was a relatively high awareness of the availability of computers (228; 63.3\%) and the internet $(223$; $61.9 \%)$, Salman's study (2016) found that these services were mostly not functional, or not available to the general public. The fact that public libraries in Nigeria generally do not provide users, especially rural ones, with access to digital information services has been lamented by Omekwu and Echezona (2009) as this lack is preventing users from accessing global resources. Eze (2013) advocated that it is imperative for Nigerian public libraries to modernise their library services by making Information and Communication Technologies (ICTs) generally available so as to help the population overcome the 'digital divide' that is depriving the society of a wider worldview, and a share in the global conversation. Okeke and Owoeye (2012) warned that, especially in times of financial crises, it is important that libraries engage in community priorities and reach out to local governments and stakeholders to ensure that they are not marginalised through being underused owing to irrelevant service delivery. Leong and Higgins (2010), in their study on the use of public library services in Singapore, described the effects of low awareness on patronage of a library, and said that lack of awareness of services could either indicate that the promotion of services or resources is inadequate, or that the services are not relevant to the needs of the community, and therefore the community does not take cognisance of their existence.

Table 3 Awareness of services offered $(\mathrm{N}=360)$

\begin{tabular}{|c|c|c|c|c|c|c|}
\hline Services/sources & Aware & $\%$ & Not aware & $\%$ & Not sure & $\%$ \\
\hline Newspapers & 292 & 81.1 & 0 & 0.0 & 68 & 18.9 \\
\hline Children's library services & 276 & 76.7 & 0 & 0.0 & 84 & 23.3 \\
\hline Bag cabinets & 289 & 80.3 & 71 & 19.7 & 0 & 0.0 \\
\hline Photocopying & 273 & 75.8 & 0.0 & 0.0 & 87 & 24.2 \\
\hline Reference & 249 & 69.2 & 5 & 1.4 & 106 & 29.4 \\
\hline Computer & 228 & 63.3 & 0 & 0.0 & 132 & 36.7 \\
\hline Internet & 223 & 61.9 & 0 & 0.0 & 137 & 38.1 \\
\hline Social magazines & 201 & 55.8 & 0 & 0.0 & 159 & 44.2 \\
\hline Study carrels & 153 & 42.5 & 29 & 8.1 & 178 & 49.4 \\
\hline New arrival display & 117 & 32.5 & 69 & 19.2 & 147 & 48.3 \\
\hline Meeting room & 95 & 26.4 & 111 & 30.8 & 154 & 42.8 \\
\hline Bindery & 89 & 24.7 & 87 & 24.2 & 184 & 51.1 \\
\hline Posters & 58 & 16.1 & 89 & 24.7 & 213 & 59.2 \\
\hline Scanning & 42 & 11.7 & 62 & 17.2 & 256 & 71.1 \\
\hline Exhibition & 13 & 3.6 & 144 & 40.0 & 203 & 56.4 \\
\hline Talking books & 11 & 3.1 & 165 & 45.8 & 184 & 51.1 \\
\hline Borrowing & 0 & 0.0 & 163 & 45.3 & 197 & 54.7 \\
\hline Library orientation & 0 & 0.0 & 204 & 56.7 & 156 & 43.3 \\
\hline Film show & 0 & 0.0 & 201 & 55.8 & 159 & 44.2 \\
\hline Awareness talks & 0 & 0.0 & 186 & 51.7 & 174 & 48.3 \\
\hline Reading clubs & 0 & 0.0 & 202 & 56.1 & 158 & 43.9 \\
\hline Braille & 0 & 0.0 & 219 & 60.8 & 141 & 39.2 \\
\hline Large print & 0 & 0.0 & 205 & 56.9 & 155 & 43.1 \\
\hline Fax & 0 & 0.0 & 160 & 44.4 & 200 & 55.6 \\
\hline
\end{tabular}

\subsection{Factors impacting on access to public library services in Nigeria}

Being aware of an information service or resource might result in a user accessing and using it. Access can, however, be hampered by a number of factors, be they of a physical, mental or psychological nature. Table 4 provides some insight into some of the factors preventing library clients from using available service. 
Table 4 Factors hampering the access to and use of public library services $(\mathrm{N}=360)$

\begin{tabular}{lcc|cc|cc}
\hline \multirow{2}{*}{ Factors hampering access } & \multicolumn{2}{c|}{ Yes } & \multicolumn{2}{c|}{ No } & \multicolumn{2}{c}{ Not sure } \\
\cline { 2 - 7 } & $\mathbf{N}$ & $\%$ & $\mathbf{N}$ & $\%$ & $\mathbf{N}$ & $\%$ \\
\hline Material not what I need & 201 & 55.8 & 20 & 5.6 & 139 & 38.6 \\
Lack of awareness & 191 & 53.1 & 35 & 9.7 & 134 & 37.2 \\
Cannot operate OPAC & 152 & 42.2 & 67 & 18.6 & 141 & 39 \\
I cannot borrow and take material home & 146 & 40.6 & 20 & 5.6 & 194 & 53.8 \\
I do not know how to search the internet and find information & 121 & 33.6 & 103 & 28.6 & 136 & 37.8 \\
Lack of literacy skills & 118 & 32.8 & 121 & 33.6 & 121 & 33.6 \\
Do not know how to search for information in books & 99 & 27.5 & 119 & 33.1 & 142 & 39.4 \\
Staff attitude & 97 & 26.9 & 185 & 51.4 & 78 & 21.7 \\
Material not usable & 89 & 24.7 & 58 & 16.1 & 213 & 59.2 \\
I am too busy & 84 & 23.3 & 102 & 28.3 & 174 & 48.3 \\
No time to listen to talking books & 73 & 20.3 & 204 & 56.7 & 83 & 23.1 \\
Location & 70 & 19.4 & 223 & 61 & 67 & 18 \\
Transportation & 4 & 1.10 & 181 & 50.3 & 175 & 48.6 \\
Accessibility to library building & 0 & 0 & 266 & 73.9 & 94 & 26.1 \\
Other hindrances & 0 & 0 & 273 & 75.8 & 87 & 24.2 \\
\hline
\end{tabular}

Combining the responses of those that could not really express an opinion about a factor with those who indicated that certain factors were problematic for them creates a bleak picture in terms of the accessibility of public library services in general. The biggest problem inhibiting access to the services was identified as the material available not being what the users required and the lack of borrowing facilities (340; $94.4 \%$ each), followed by a lack of awareness of what services are being offered $(325 ; 91.3 \%)$, and the material not being usable $(302 ; 83.9 \%)$. The fact that only $5.6 \%$ of respondents expressed satisfaction with the available material, and that the material was mostly deemed unusable is a grave concern. The lack of relevant materials, not enough computers and staffing challenges were problems mentioned by the librarians. In their studies, Aniebo (2007), Abolaji (2009) and Sultana (2014) found similar trends, where their respondents identified disorganised and non-current library material, too few copies, non-functional library catalogues, inadequate resources or facilities, staff attitudes, and a lack of professionally qualified library staff as factors hampering access to library facilities. Lack of information literacy and information-seeking skills was also identified in the current study as contributing factors that hampered access to library services and their use.

\subsection{Use of public library facilities and sources}

The respondents were asked to indicate how often they used the public library facilities. Figure 4 gives an indication of the user patterns in terms of frequency. Frequenting public libraries to make use of the available services seems to be mainly an ad hoc rather than a regular occurrence, with only nine $(2 \%)$ respondents indicating that they use the library on a very regular basis, and $39(11 \%)$ using it regularly. Within the rural libraries, no one indicated that they used them on a very regular basis.

Figure 4 Frequency of use $(\mathrm{N}=360)$

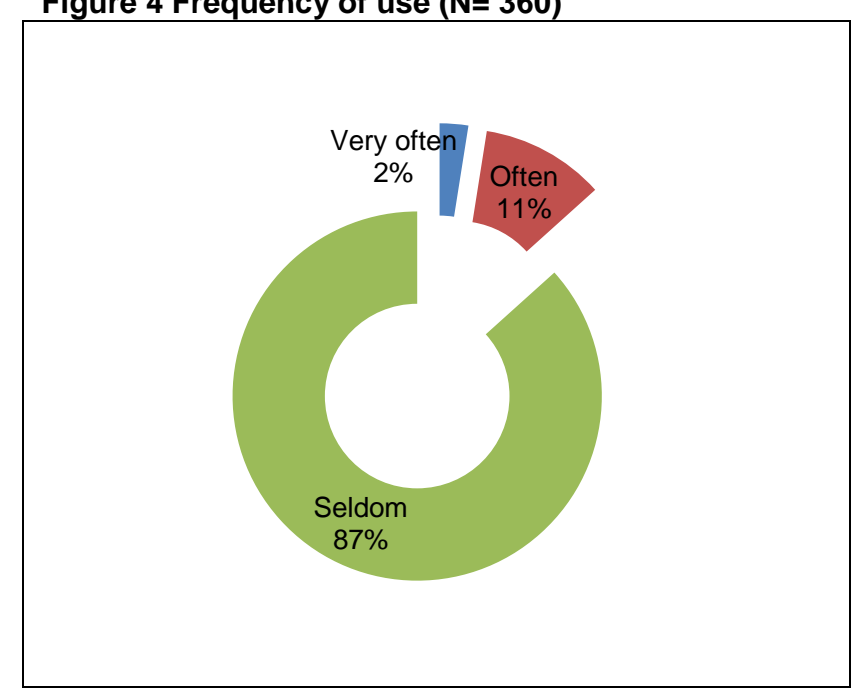


When the respondents were asked to indicate which services they used, on a scale of 'often', 'seldom', or 'never', the response showed a sombre picture as to the use of most of the services normally offered by public libraries (see Table 5). In contradiction to this finding, Ikenwa and Adegbilero-Iwari (2014) found that $42 \%$ of users of public libraries in the southwest region of Nigeria used them on a daily basis. This trend was confirmed by Oluwaseunfunmi's (2015) study, which found that $57.6 \%$ of the young adults sampled frequented the Oyo State public library on a daily basis. A reason for this contradiction could be the fact that these two studies concentrated on areas near major cities where access to libraries is much easier than in the more remote areas or smaller cities in the other regions. The librarians from the urban areas indicated that they experienced relatively high levels of patronage, while the rural librarians were unanimous in their opinion that the patronage of the library was low.

\subsection{Utilisation patterns}

To establish the patterns of usage among the available services, respondents were asked to indicate which services they used based on a scale ranging from 'often' to 'never'. Table 5 reflects their responses.

Table 5 Use of library services and information sources $(N=360)$

\begin{tabular}{lcc|cc|cc}
\hline Services/sources & Often & $\%$ & Seldom & $\%$ & Never & $\%$ \\
\hline Bag cabinet & 241 & 66.9 & 106 & 29.4 & 13 & 3.6 \\
Photocopying & 134 & 37.2 & 189 & 52.5 & 37 & 10.3 \\
Reading newspapers & 113 & 31.4 & 244 & 67.8 & 3 & 0.8 \\
Reading social magazines & 76 & 21.1 & 274 & 76.1 & 10 & 2.8 \\
Using the computer & 34 & 9.4 & 260 & 72.3 & 66 & 18.3 \\
Using bindery services & 1 & 0.3 & 28 & 7.8 & 331 & 91.9 \\
Borrowing of material & 0 & 0.0 & 0 & 0.0 & 360 & 100.0 \\
Using reference services & 0 & 0.0 & 233 & 64.7 & 127 & 35.5 \\
Children's library services & 0 & 0.0 & 46 & 12.8 & 314 & 87.2 \\
Internet & 0 & 0.0 & 176 & 48.9 & 184 & 51.1 \\
Talking books & 0 & 0.0 & 0 & 0.0 & 360 & 100.0 \\
Attending library orientation & 0 & 0.0 & 59 & 16.4 & 301 & 83.6 \\
Film show & 0 & 0.0 & 0 & 0.0 & 360 & 100.0 \\
Exhibitions & 0 & 0.0 & 50 & 13.9 & 310 & 86.1 \\
Checking new arrival display & 0 & 0.0 & 129 & 35.8 & 231 & 64.2 \\
Looking at posters & 0 & 0.0 & 133 & 36.9 & 227 & 63.10 \\
Attending awareness talks & 0 & 0.0 & 0 & 0.0 & 360 & 100.0 \\
Belonging to a reading club & 0 & 0.0 & 0 & 0.0 & 360 & 100.0 \\
For entertainment purposes & 0 & 0.0 & 3 & 0.8 & 357 & 99.2 \\
Using Braille sources & 0 & 0.0 & 0 & 0.0 & 360 & 100.0 \\
Using Large print sources & 0 & 0.0 & 63 & 17.5 & 297 & 82.5 \\
Scanning & 0 & 0.0 & 102 & 28.3 & 258 & 71.7 \\
Faxing & 0 & 0.0 & 0 & 0.0 & 360 & 100.0 \\
Study carrels & 0 & 0.0 & 35 & 9.7 & 325 & 90.3 \\
Meeting rooms & 0 & 0.0 & 29 & 8.1 & 331 & 91.9 \\
\hline & & & & & & \\
\hline
\end{tabular}

The information services used most often were the photocopying service $(134 ; 37.2 \%)$, the reading of newspapers $(113 ; 31.4 \%)$ and the reading of social magazines $(76 ; 21.1 \%)$. Most of the other services offered were seldom or never used. The high use of the library to make photocopies and read newspapers can be confirmed by several other studies, for example Obinyan, Obinyan, and Aidenojie (2011) and Omotosho and Okiki (2012). The high levels of newspaper and photocopying use were confirmed by the librarians. In the opinion of one urban librarian,

Those library users who know the value of the library access and use the services provided. We have eighteen computers meant for staff use, three OPAC computers for library users, and four for the elibrary. But because of lack of funds, these computers, especially those for users, cannot be maintained, and they have packed up." 
Providing reasons for low patronage a librarian explained that,

Some are satisfied, while the majority are not satisfied owing to the inadequacy and outdated nature of the available resources. The format of materials in print dominate, there is ineffective promotion of services, inadequate space and lack of ICT skills of staff."

A rural librarian lamented:

I do not think the users are accessing and using the services optimally, because we do not have enough books for adults and children. We also do not have computers.

\subsection{Satisfaction with public library services and sources}

Utilisation of sources is to quite an extent influenced by how satisfied users are with the specific service or services available to them. It can be assumed that the need for a service, awareness of its existence, and its easy availability will all be factors that could play a role in the level of satisfaction a library user will experience when using the public library services available. The users were therefore requested to express their levels of satisfaction with specific services and information sources that can commonly be expected to be provided by public libraries in Nigeria. The results are shown in Table 6 .

Table 6 User satisfaction with public library service delivery

\begin{tabular}{|c|c|c|c|c|c|c|c|c|c|c|}
\hline \multirow{3}{*}{ Services } & \multicolumn{10}{|c|}{ Totals } \\
\hline & \multicolumn{2}{|c|}{ Very satisfied } & \multicolumn{2}{|c|}{ Satisfied } & \multicolumn{2}{|c|}{ Less satisfied } & \multicolumn{2}{|c|}{ Not satisfied } & \multicolumn{2}{|c|}{ Don't use } \\
\hline & $\mathbf{N}$ & $\%$ & $\mathbf{N}$ & $\%$ & $\mathbf{N}$ & $\%$ & $\mathbf{N}$ & $\%$ & $\mathbf{N}$ & $\%$ \\
\hline Bag cabinet & 0 & 0.0 & 206 & 57.2 & 116 & 32.2 & 1 & 0.3 & 37 & 10.3 \\
\hline Photocopying & 0 & 0.0 & 117 & 32.5 & 207 & 57.50 & 5 & 1.4 & 31 & 8.6 \\
\hline Newspapers & 3 & 0.8 & 105 & 29.2 & 206 & 57.2 & 45 & 12.5 & 1 & 0.3 \\
\hline Reference & 0 & 0.0 & 49 & 13.6 & 180 & 50.0 & 43 & 11.9 & 88 & 24.4 \\
\hline Social magazines & 3 & 0.8 & 44 & 12.2 & 219 & 60.8 & 60 & 16.7 & 34 & 9.4 \\
\hline Computers & 0 & 0.0 & 38 & 10.6 & 200 & 55.6 & 32 & 8.9 & 90 & 25.0 \\
\hline Internet & 0 & 0.0 & 17 & 4.7 & 142 & 39.4 & 70 & 19.4 & 131 & 36.4 \\
\hline Study carrels & 0 & 0.0 & 13 & 3.6 & 79 & 21.9 & 11 & 3.1 & 257 & 71.4 \\
\hline Meeting room & 0 & 0.0 & 10 & 2.8 & 10 & 2.8 & 0 & 0.0 & 340 & 94.4 \\
\hline Bindery & 0 & 0.0 & 8 & 2.2 & 64 & 17.8 & 1 & 0.3 & 287 & 79.7 \\
\hline New arrival displays & 0 & 0.0 & 7 & 1.9 & 80 & 22.2 & 68 & 18.9 & 205 & 56.9 \\
\hline Posters & 0 & 0.0 & 3 & 0.8 & 109 & 30.3 & 62 & 17.2 & 186 & 51.7 \\
\hline Borrowing & 0 & 0.0 & 0 & 0.0 & 0 & 0.0 & 0 & 0.0 & 360 & 100.0 \\
\hline Children's library services & 0 & 0.0 & 0 & 0.0 & 21 & 5.8 & 13 & 3.6 & 326 & 90.6 \\
\hline Talking books & 0 & 0.0 & 0 & 0.0 & 5 & 1.4 & 3 & 0.8 & 352 & 97.8 \\
\hline Library orientation & 0 & 0.0 & 0 & 0.0 & 34 & 9.4 & 15 & 4.2 & 311 & 86.4 \\
\hline Film show & 0 & 0.0 & 0 & 0.0 & 0 & 0.0 & 0 & 0.0 & 360 & 100.0 \\
\hline Exhibition & 0 & 0.0 & 0 & 0.0 & 30 & 8.3 & 6 & 1.7 & 324 & 90.0 \\
\hline Awareness talk & 0 & 0.0 & 0 & 0.0 & 0 & 0.0 & 0 & 0.0 & 360 & 100.0 \\
\hline Reading club & 0 & 0.0 & 0 & 0.0 & 0 & 0.0 & 0 & 0.0 & 360 & 100.0 \\
\hline Entertainment & 0 & 0.0 & 0 & 0.0 & 28 & 7.8 & 44 & 12.2 & 288 & 80.0 \\
\hline Braille & 0 & 0.0 & 0 & 0.0 & 0 & 0.0 & 0 & 0.0 & 360 & 100.0 \\
\hline Large print & 0 & 0.0 & 0 & 0.0 & 0 & 0.0 & 14 & 3.9 & 346 & 96.1 \\
\hline Scanning & 0 & 0.0 & 0 & 0.0 & 0 & 0.0 & 0 & 0.0 & 0 & 0.0 \\
\hline Fax & 0 & 0.0 & 0 & 0.0 & 0 & 0.0 & 0 & 0.0 & 360 & 100.0 \\
\hline
\end{tabular}

Table 6 shows that, with the exception of three services/facilities (the availability of bag cabinets to store personal items while using the library, the photocopying facilities and the availability of newspapers), users were in general very dissatisfied with the services and information resources delivered by the public libraries, and most of the services were not used at all. Non-use might be due to a service not being available, or poor awareness that these services are available. The only services that attracted a 'very satisfied' response were the availability of social magazines and newspapers, with three $(0.8 \%)$ responses each. One of the librarians acknowledged awareness of user dissatisfaction by commenting that, "we do 
not have enough materials to satisfy the community". Another lamented that, "the library is not well patronised owing to a lack of adequate facilities, illiteracy, irrelevant services and lack of awareness". Explaining why service delivery is unsatisfactory a librarian commented, "the public library is poorly funded, therefore, most of the time we are handicapped in our operational activities", while another one attributed it to the frequent changes in the government and commissioners of the responsible ministry which handicap their operational activities.

A study done by Akhtar (2008) and Oluwaseunfunmi (2015) found similar trends of user dissatisfaction among public library users in Nigeria, though Iwhiwhu and Okorodudu's (2012) study found that users generally were satisfied with public library services in Edo State. It would thus seem as if service delivery levels might differ among some of the states, but as the current study covered a number of states, all of which seem to agree that service delivery is unsatisfactory, it might be an indication that high satisfaction with service delivery is an exception rather than a norm.

\subsection{Factors hampering satisfactory use of libraries}

An additional question asked users to elaborate on what hampers their satisfactory use of the library services. They responded that some of the challenges affecting access to and use of the library services were: the irregular supply of electricity; disorganised and non-current library material; too few available copies of information sources; non-functional library catalogues; inadequate resources/facilities; the attitude of staff; and the lack of professionally qualified library staff. The librarians were mostly in agreement with the users on these issues and elaborated on what they saw as the major causes as follows: in terms of staffing, one librarian indicated that,

We have a serious challenge in the area of staffing where inexperienced staff are transferred from the Ministry to the library. These are Ministry staffers who know little or nothing about the library profession. This poses a lot of challenges in the daily running of the library activities.

In terms of service delivery a librarian lamented that,

financial stress, insecurity of books occasioned by students pilfering of the books, the exodus of public library staff to academic libraries for higher pay are some of the challenges experienced in the provision of library services.

The lack of e-library facilities, poor working environments and working tools and irregular electricity supply were also identified as challenges.

The issues mentioned were also identified in studies done by Abolaji (2009), Aniebo (2007), Sultana (2014) and Oluwaseunfunmi (2015). These studies additionally established that use of, and satisfaction with, library services was influenced by an awareness of what was available, the ability to use the OPAC, currency of material, and access to the services. Access to services is influenced by the nature of the library buildings where a lack of ramps would prevent the physically impaired from visiting the upper floors of the libraries. The low level of satisfaction of public library users in Nigeria confirms the lack of the required services needed by the library patrons, which are the predictors of customer satisfaction (Okibo \& Ogwe 2013). In this regard, Shah (2013) pointed out that user satisfaction is enhanced by the quality and quantity of the services provided by a library because the robustness of the services is a catalyst to satisfaction. To this, Oghenetega, Okeke and Umeji (2014) added that the extent to which patronage and satisfaction of service delivery is achieved is premised on the size and direction of product performance.

\subsection{Suggestions for the improvement of satisfaction levels}

Asked how their levels of satisfaction could be improved, the answers reflected in Table 7 were provided.

Table 7 Improvement suggestions

\begin{tabular}{|c|c|c|}
\hline & Number & $\%$ \\
\hline Urgent need for improvement in the quality and quantity of the services provided, & 219 & 60.8 \\
\hline Facilities should be improved, and awareness strategies put in place so that users can be sensitised on the available services & 153 & 42.5 \\
\hline Adequate funds should be provided to run the libraries & 219 & 60.8 \\
\hline Introduce new and relevant services & 181 & 50.3 \\
\hline The quality and quantity of library staff should be improved. & 181 & 50.3 \\
\hline
\end{tabular}

A librarian added to these by suggesting that, "we need to improve on our awareness strategies and the level of services that we provide". Another indicated that improvements could be implemented

through awareness mechanisms in the radio, newspapers and community meetings. New and relevant services must be introduced, and the environment made more conducive for reading, relaxation and entertainment. 
The issue of the improvement of the erratic electricity situation was also mentioned and it was suggested that "constant electricity should be supplied by maintaining the existing generator as a stopgap measure when there is power outage." From these suggestions it can be deduced that attention should be paid by the governing bodies to the level and quality of service delivery, promotion of services and staff issues so as to keep the attention of the current user. In a world where a wide variety of information services are available from which users can choose, libraries might lose their appeal and permanently be side-lined by a fickle user community.

\section{Conclusions}

The study, covering Nigeria as a whole, has shown that lack of awareness of services that are available, as well as the lack of access to many of the services that users would have liked to have access to, have a major impact on the utilisation of these services. As the study has not looked at how services are marketed to the public, it would be worthwhile to investigate whether a lack of effective marketing has contributed to the low awareness of what services are available, resulting in low patterns of usage among users and non-users alike. However, even if awareness could be raised, the issue of inappropriate available reading and informational material would need to be addressed before users could be expected to be satisfied with what is available to them. User satisfaction is closely related to the issues of sufficient funding to buy what is required, and a proper needs analysis to establish what the public expect from the services rendered to them is needed. The study found that, though most of the respondents were students who use the facilities for a variety of reasons, users from a wide range of occupations and educational levels were found to be using the library, and therefore their needs should be established and reflected in the library collections and services. Of concern was that the study found that those who frequent the libraries were mainly educated males, an indication that a large group of potential users are not aware that, based on the UDHR and IFLA public library service guidelines, public libraries should provide relevant services to all community members regardless of their literacy levels, gender or cultural orientation.

Evaluated against the IFLA public library service guidelines (Koontz \& Gubbin 2010), Nigerian public libraries seem still to be struggling to provide efficient services to the general public. As there is a strong correlation between government support and proper funding, and the use of services offered, it might therefore be in the best interest of all stakeholders to start interacting with each other by way of constructive dialogue and organised meetings, both at government and grassroots level, to find common ground on user expectations and government responsibilities in terms of service delivery. Should this not happen, public libraries in Nigeria could be doomed to become unused relics, serving no purpose or function. Based on the principles of the UDHR, public libraries are seen and used as vehicles for providing communities with crucial information for their development, empowerment and entertainment. It is imperative that the Nigerian public library services be rejuvenated and adapted to the specific needs of the population, especially those in rural areas, so that both the country and the individuals living in it can grow and prosper.

\section{Recommendations}

The following recommendations are therefore made:

- $\quad$ Since most of the services provided in the public libraries studied were seemingly irrelevant, not current, or needed maintenance or upgrading, the libraries should embark on finding innovative ways to improve their services to become more relevant to the needs of the community. Community involvement is of paramount importance as members could have suggestions or practical skills that could be used to assist the libraries.

- The borrowing of materials is a service that should be reintroduced as a core function of public libraries so as to allow members to use library materials at their leisure and in their own time for information or leisure purposes.

- Awareness strategies need to be developed through advertising in the media, library orientation weeks, community forums, town hall meetings and any other innovative means that can be employed to create awareness of the library as an institution, but also of the services and information sources it offers.

- $\quad$ Libraries should provide information literacy training so that their material can be more accessible to library users.

- Libraries need to become aware of people with special needs within their communities in order to provide adequately for them.

- Each section of a library should have computers with internet access, both for administrative functions and for the library users.

\section{References}

Abolaji, J.A. 2009. How libraries contribute to communities and society. Ozean Journal of Social Sciences, 2(3): $197-205$.

Abdel-Motey, Y.Y. and Al-Ansari, H. 2012. Public libraries in Kuwait : a study of their resources, facilities and services. Public Library Quarterly, 22(2): 23-37.

Adeniyi, A.I. and Subair, R.E. 2013. Accessing indigenous knowledge resources in libraries and the problems encountered by librarians managing IK in Oyo State, Nigeria. Library Philosophy and Practice. [Online]. http://digitalcommons.unl.edu/cgi/viewcontent.cgi?article=2391\&context=libphilprac (3 July 2013).

Akhtar, M.Z. 2008. Library services and user satisfaction. Pakistan Library \& Information Science Journal, 39(2), 25-34.

Amodeo, A.J. and Carter, T.L. 1999. Introduction to library public services. Library and Information Science Text Series. Englewood: Libraries Unlimited. 
Aniebo, M.U. 2007. Library services for effective information management in local government administration in Nigeria. Coal City Libraries 3. Owerri: New Springfield.

Badawi, G. 2009. Public library services and the information needs of women in Northern Nigeria. Samaru Journal of Information Studies, 9(2):1-7.

Bamise, O.F. and Oyedapo, R.O. 2012. Comparative evaluation of adolescents' use of public libraries in the Nigerian States of Osun and Oyo. Public Library Quarterly, 31(3), 256-266.

Clarke, C., Yu, L., Yu, C. and Fu, L. 2011. How far can we go in ensuring equality of access to public library services? The re-visitation of a core professional value in the context of regional and urban-rural inequalities in China. Libri, 61(1): 23-36.

Creswell, J.W. and Plano Clark, V.L. 2007. Designing and conducting mixed methods approaches. Thousand Oaks, CA: Sage.

Ebiwolate, P.B. 2010. Nigeria public library service to rural areas: libraries in Niger Delta States. Library Philosophy and Practice. [Online]. http://digitalcommons.unl.edu/cgi/viewcontent.cgi?article=1380\&context=libphilprac (14 July 2014).

Eze, J.U. 2013. Staff training programme in Nigerian public libraries: the case of Enugu State Public Library. [Online]. http://digitalcommons.unl.edu/cgi/viewcontent.cgi?article=1882\&context=libphilprac (9 October 2014).

Gardner, F.M. 1971. Public library legislation: a comparative study. Paris: UNESCO

Harris, J. 1970. Libraries and librarianship in Nigeria at mid-century. Paper delivered at the Nigerian Library Association Conference. Lagos. 2 April. [Online]. https://eric.ed.gov/?id=ED053768 (14 January 2013).

IFLA/UNESCO. 1994. IFLA/UNESCO Public Library Manifesto 1994. IFLA. [Online]. http://www.ifla.org/publications/iflaunesco-public-library-manifesto-1994 (21July 2013)

Ikenwa, I.J. and Adegbilero-Iwari, A. 2014. Utilization and user satisfaction of public library services in South-West, Nigeria in the $21^{\text {st }}$ Century: A Survey. International Journal of Library Science, 3(1): 1-6.

Israel, G.D. 1992. Sampling the evidence of extension program impact. Florida: University of Florida Cooperative Extension Service, Institute of Food and Agriculture Sciences.

Iwhiwhu, B.E. and Okorodudu, P.O. 2012. Public library information resources, facilities, and services : user satisfaction with the Edo State Central. Library Philosophy and Practice, 51-65. [Online]. http://digitalcommons.unl.edu/cgi/viewcontent.cgi?article=1821\&context=libphilprac (6 June 2015).

Kim-Soon, N., Hasbi, N.M. and Ahmad, A. 2013. An investigation of user satisfaction on the library information resources, facilities, and services of a public university. Proceedings $2^{\text {nd }}$ International Conference on Technology Management, Business and Enterpreneurship. 4-6 December, 2013. Melacca, Malaysia.

Koontz, C. and Gubbin, B., Eds. 2010. IFLA Public Library Service Guidelines (Vol. 147). Berlin: de Gruyter.

Leong, I. C. B. and Higgins, S. E. 2010. Public library services for wheelchair-bound young people in Singapore. Public Library Quarterly, 29(3): 210-229.

Librarians' Registration Council of Nigeria. 2015. Report on the state of public libraries in Nigeria by Librarians' Registration Council of Nigeria. [Online]. https://www.google.com/search?q=Librarians\%27+Registration+Council+of+Nigeria (5 January 2016)

Obasi, N.F.K. 2015. Indices of access to information in nigerian public libraries and citizens' political participation. [Online]. http://creativecommons.org/licenses/by/3.0/ (21 December 2016).

Obinyan, G.A., Obinyan, O.O. and Aidenojie, E. 2011. Use of information resources in four branches of a state public library in Nigeria. Chinese Librarianship: an International Electronic Journal, 31: 1-15.

Ocholla, D. 2006. Information accessibility by the marginalised communities in South Africa and the role of libraries. Paper presented at the 72nd IFLA General Conference and Council. 20-24 August 2006. Seoul, Korea. [Online]. http://arizona.openrepository.com/arizona/bitstream/10150/105134/1/Ocholla+Faife+ifla+2006+October+2006+6th.pd $f(13$ March 2014)

Ogbonna, I.M. 2014. Books, libraries and reading in the digital Age. Enugu, Nigeria: Eminota Publishers.

Oghenetega, L.U., Okeke, I.E. and Umeji, E.C. 2014. Availability and uses of ICT facilities among students in Faculty of Social Science, Madonna University, Okija. International Research: Journal of Library and Information Science, 4(2), 346-356.

Ojo-Igbinoba, M.E. 1993. The practice of conservation of library materials in sub-Saharan Africa. Bloomington : African Studies Program, Indiana University.

Okeke, R. and Owoeye, J. 2012. Public libraries as community kitchens: an overview of public libraries in Lagos State. PNLA Quarterly, 76(2): 74-87.

Okibo, B.W. and Ogwe, S.L. 2013. An assessment of factors affecting quality customer care services in Telkom Kenya. [Online]. http://www.hausarbeiten.de/faecher/vorschau/211772.html (26 November 2014).

Oluwaseunfunmi, O.A. 2015. Public Libraries in Nigeria: resources and services for young adults. International Journal of Library and Information Science Studies, 1(2):1-13.

Omekwu, C.O. and Echezona, I.R. 2009. Emerging challenges and opportunities for Nigerian Libraries in a global information environment. Library Review, 58: 482-492.

Omotosho, D. 2014. Eight Jire Olanlokun memorial lecture. Unilorin Bulletin, 9 (45).

Omotosho, A.M. and Okiki, O.C. 2012. Challenges of public library patrons in the use of information services for attainment of Health Millennium goals. Library Philosophy and Practice. [Online]. http://digitalcommons.unl.edu/cgi/viewcontent.cgi?article=1832\&amp;context=libphilprac (30 June 2017). 
Opaleke, J.S.1997. Public library services in Nigeria: clientele evaluation of Offa Township Library. Rural Libraries, 17(2): 25-42.

Oyeronke, A. 2012. Information as an economic resource: the role of public libraries in Nigeria. Chinese Librarianship, 34: 66-75.

Polit, D. F. and Beck, C.T. 2004. Nursing research: principles and methods. $7^{\text {th }}$ ed. Philadelphia: Lippincott, Williams Wilkens.

Saleh, A.G. and Lasisi, F.I. 2011. An assessment of public library services in north- eastern Nigeria. Library Philosophy and Practice. [Online]. http://digitalcommons.unl.edu/libphilprac/507/ (8 June 2014).

Salman, A.A. 2006. From papyrus to machine-readable: a survey of the history of libraries. Oshogbo: Positive Impact Communication.

Salman, A.A. 2016. Provision and utilisation of public library services in nigeria. PhD thesis. University of Zululand.

Shah, U.N. 2013. User satisfaction levels of SCEE NUST Library from library service quality. Library Philosophy and Practice. [Online]. http://digitalcommons.unl.edu/cgi/viewcontent.cgi?article=2292\&context=libphilprac (29 June 2017).

Sultana, R. 2014. Rural library services : lessons from five rural public libraries in West Bengal. International Journal of Humanities and Social Science Invention, 3(10), 27-30.

Tyagi, S. 2011. Use of information resources and services at Delhi Public Library (DPL): a survey. Library Philosophy and Practice. [Online]. http://www.webpages.uidaho.edu/ mbolin/tyagi2.htm (18 April 2012).

United Nations. 1948. United Nations Universal Declaration of Human Rights. Paris: United Nations.

UNESCO. 1953. Seminar on the development of public libraries in Africa. [Online]. http://www.unesdoc.unesco.org/images/0012/001272/127287EB.pdf (23 July 2013)

United Nations. 2008. The Universal Declaration of Human Rights: a living document. [Online]. http://www.un.org/en/events/humanrightsday/udhr60/declaration.shtml (14 September 2014).

Uzuebgu,C.P. and Onyekweodiri, N.E. 2011. The professional visibility of the Nigerian Library Association: a report of survey findings. Library Philosophy and Practice [Online]. http://digitalcommons.unl.edu/cgi/viewcontent.cgi?article=1672\&context=libphilprac (24 April 2014).

Yusufu, A. 2010. Libraries and sustainability of the democratic order: the place of

public library system in Nigeria. In Education for sustainable development in Nigeria. S. Talla et al., Eds. Zaria: Ahmadu Bello University. 229-236.

Zambia Library Association. 1987. National information policy for Zambia: a draft proposal. Lusaka: ZLA. 